\title{
ANALISIS PRESTASI BELAJAR MAHASISWA LULUSAN SEKOLAH MENENGAH UMUM DAN SEKOLAH MENENGAN KEJURUAN
}

\author{
Sirajuddin Saleh ${ }^{1 *}$, Jufari Jufari $^{2}$, Muh. Nasrullah $^{3}$ \\ ${ }_{1,2,3}$ Fakultas Ilmu Sosial, Universitas Negeri Makassar, Indonesia \\ sirasaleh1971@gmail.com ${ }^{1}$,jufari2016@gmail.com ${ }^{2}$,nasrullahmujetaba@gmail.com ${ }^{3}$ \\ *Corresponding author
}

\begin{abstract}
Abstrak: Analisis Prestasi Belajar Mahasiswa Lulusan Sekolah Menengah Umum dan Sekolah Menengan Kejuruan. Penelitian bertujuan untuk menganalisis perbedaan prestasi belajar mahasiswa lulusan Sekolah Menengah Umum dan Sekolah Menengah Kejuruan dan untuk menganalisis faktor yang mendukung dan menghambat prestasi belajar mahasiswa.. Subjek penelitian adalah mahasiswa pada program studi Pendidikan Administrasi Perkantoran Fakultas Ilmu Sosial Universitas Negeri Makassar. Penelitian ini menggunakan pendekatan kuantitatif, jenis ex post facto dengan eksplanasi komparatif. Populasi pada penelitian ini sebanyak 335 mahasiswa. Sampel penelitian sebanyak 167 mahasiswa yang diambil menggunakan metode probability sampling. Pengumpulan data menggunakan teknik observasi, wawancara, dan dokumentasi. Pengujian hipotesis menggunakan uji F, anava, dan t-Test. Hasil penelitian menunjukkan: 1) Prestasi belajar mahasiswa lulusan Sekolah Menengah Umum rata-rata 3,72 dan lulusan Sekolah Menengah Kejuruan rata-rata 3,77; 2) Tidak terdapat perbedaan signifikan prestasi belajar antara mahasiswa lulusan Sekolah Menengah Umum dan Sekolah Menengah Kejuruan; 3) Faktor-faktor pendukung prestasi belajar meliputi: motivasi belajar, inteligensi, konsentrasi, tujuan yang ingin dicapai, rajin kuliah dan mengerjakan tugas, keaktifan dalam perkuliahan, manajemen waktu yang baik, suasana belajar yang kondusif, dan hubungan mahasiswa dengan dosen. Faktor penghambat: malas, jarak tempat tinggal yang jauh, persepsi mahasiswa salah jurusan, jadwal kuliah sore, dan metode pembelajaran yang monoton.
\end{abstract}

Kata kunci: prestasi belajar, indeks prestasi komulatif, hasil belajar, sekolah menengah umum, sekolah menengah kejuruan.

\begin{abstract}
Analysis of Student Achievement of Graduates of Senior High School and Vocational High School. The research aims to analyze the differences in the learning achievement of students who graduate from Senior High School and Vocational High School and to analyze the factors that support and hinder student achievement. The research subjects are students in the Office Administration Education study program, Faculty of Social Sciences, Makassar State University. This research uses a quantitative approach, ex post facto type with comparative explanation. The population in this study were 335 students. The research sample was 167 students who were taken using probability sampling method. Collecting data using observation, interview, and documentation techniques. Hypothesis testing uses the F test, ANOVA, and tTest. The results showed: 1) The learning achievement of students graduating from Senior High School was 3.72 on average and Vocational High School graduates had an average of 3.77; 2) There is no significant difference in learning achievement between students who graduated from Senior High School and Vocational High School; 3) Supporting factors for learning achievement include: learning motivation, intelligence, concentration, goals to be achieved, diligent in studying and doing assignments, activeness in lectures, good time management, a conducive learning atmosphere, and student relations with lecturers. Inhibiting factors: laziness, distance to live far away, student perceptions of misdirection, afternoon class schedules, and monotonous learning methods.
\end{abstract}

Keywords: learning achievement, grade point average, learning outcomes, senior high schools, vocational high schools.

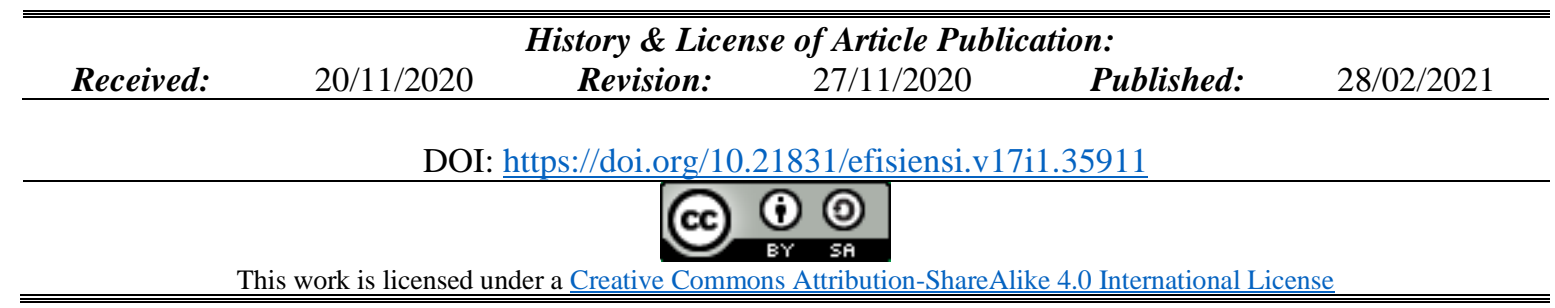


Edisi Februari 2021, Volume 18 Nomor 1, ISSN 1412-1131, e-ISSN 2528-5750, Halaman 29-44

\section{PENDAHULUAN}

Pendidikan dilaksanakan untuk memenuhi dan mencapai kualitas hidup manusia di masa yang akan datang (Akçay \& Akyol, 2014; Arhas, 2018; Ikhsan et al., 2019; Muslimin et al., 2019). Dalam perkembangannya pendidikan lebih menekankan pada profesionalitas. Pendidikan tinggi merupakan salah satu jenjang pendidikan yang diselenggarakan untuk mencetak sumber daya manusia berkualitas. Untuk melahirkan sumber daya manusia berkualitas, tergantung pada kegiatan pembelajaran yang diselenggarakan oleh perguruan tinggi (Darwis, Amelia, et al., 2019; M. Nasrullah et al., 2018). Berhasil tidaknya kegiatan paling pokok tersebut dapat dilihat pada prestasi belajar mahasiswa sebagai hasil proses pembelajaran yang telah dilalui oleh mahasiswa. Hasil dari belajar atau prestasi belajar yang dicapai mahasiswa biasanya diberikan dalam bentuk nilai yang telah ditetapkan berdasarkan kriteria tertentu (Jansen et al., 2019; Liu et al., 2020; Schrader \& Grassinger, 2021; Sung, 2017).

Belajar sebagai proses perubahan pola pikir dan pola prilaku sebagai akibat adanya interaksi dengan lingkungan. Hal ini membuktikan bahwa seseorang dikatakan telah belajar apabila ada perubahan yang terjadi pada aspek perilaku sebagai hasil dari pengalaman. Hasil belajar merupakan prestasi yang diperoleh peserta didik berdasarkan kriteria atau nilai yang telah ditetapkan (Niswaty \& Arhas, 2019; Suprianto et al., 2018, N. Nasrullah, 2017, Hosnan, 2014). Hasil belajar sebagai indikator untuk mengetahui tingkat pencapaian belajar sebagai bukti atas keberhasilan dan kemampuan peserta didik sesuai bobot yang dicapainya (Hamdu \& Agustina, 2011). Hasil belajar dapat diinterprestasikan peserta didik dikatakan berhasil dalam pembelajaran dan diakui kemampuannya apabila telah berprestasi. (Yusman et al., 2019), (Alfiyah \& Hisyam, 2015). Pendapat tersebut dapat diinterprestasikan bahwa mereka dikatakan berhasil dalam pembelajaran dan diakui kemampuannya apabila telah berprestasi.

Dalam kegiatan perkuliahan, mahasiswa dituntut berkompetisi untuk memperoleh prestasi akademik dalam yang disebut Indeks Prestasi Komulatif (IPK) Semakin baik penguasaan akademik pada proses pembelajaran yang dilakukan maka baik pula prestasi akademik yang akan dicapai. Pencapaian prestasi belajar mahasiswa tentu berbeda-beda setiap individu. Prestasi dinyatakan dengan indikator, seperti: nilai rapor, IPK, atau predikat kelulusan. (Widowati, 2017). Hasil tersebut diukur dengan skor atau angka dan dikumpulkan berupa nilai rapor pada jenjang sekolah atau indeks prestasi kumulatif pada perguruan tinggi (Darwis, Batari, et al., 2019; Pope, 2019). 
Keberhasilan suatu proses pendidikan didasarkan pada tingkat prestasi akademik maupun non akademik. Prestasi akademik merupakan penilaian hasil belajar yang dapat diukur secara kuantitatif yang dinyatakan dalam bentuk angka yang dituangkan dalam Indeks Prestasi Kumulatif (IPK) dari beberapa semester. Nilai yang diperoleh pada pendidikan tinggi menggunakan rentang 2,76-3,00 (memuaskan), 3,01-3,50 (sangat memuaskan), >3,50 (pujian/cumlaude). Predikat kelulusan dengan pujian (cumlaude) tentu menjadi impian bagi semua mahasiswa, tetapi hal itu tidak akan menjadi kenyataan apabila IPK yang diperoleh rendah atau tidak memenuhi standar. Selain itu, hasil belajar yang dicapai setiap mahasiswa tidaklah sama, hal ini dipengaruhi oleh berbagai faktor.

Faktor yang sangat mempengaruhi prestasi mahasiswa yaitu latar belakang mahasiswa, baik latar belakang pribadi maupun latar belakang pendidikannya atau asal sekolahnya. Mahasiswa yang berasal dari lulusan atau latar belakang pendidikan sekolah menengah umum lebih fokus pada aspek pengembangan kognitif/pengetahuan teoretis. Mahasiswa yang berasal dari lulusan sekolah menengah kejuruan lebih memfokuskan pada pengembangan sikap profesional untuk bekal memasuki lapangan kerja (Mardiyah et al., 2017). Secara teoritis mahasiswa yang berlatar belakang pendidikan SMK memiliki prestasi akademik yang lebih tinggi dibanding dengan mahasiswa yang berlatar belakang pendidikan SMU, karena mahasiswa yang berasal dari lulusan SMK dilatar belakangi oleh pendidikan yang bersifat praktek keahlian. Selain itu, pengalaman belajar dengan mata pelajaran yang serumpun dengan yang didapat di perguruan tinggi sangat membantu pembelajaran. Dapat dipahami bahwa mahasiswa yang berlatar belakang pendidikan SMK tidak mendapat hambatan dalam proses pembelajarannya di perguruan tinggi.

Latar belakang pendidikan mahasiswa yang berbeda sewaktu mengikuti pendidikan pada jenjang SLTA sebagai input perguruan tinggi merupakan masalah tersendiri dalam proses pembelajaran pada perguruan tinggi khususnya pada Program Studi Pendidikan Administrasi perkantoran. Seyogianya untuk memperlancar proses perkuliahan, input mahasiswa adalah mereka yang berasal dari program keahlian manajemen perkantoran di SMK. Prestasi belajar mahasiswa sering kali dikaitkan dengan latar belakang pendidikan atau asal sekolah mahasiswa yang beragam (SMU dan SMK baik swasta maupun negeri).

Lulusan SMK khususnya rumpun administrasi perkantoran lebih mudah memahami pembelajaran di tingkat perguruan tinggi khususnya administrasi perkantoran karena saat dibangku SMK mereka sudah memperoleh bekal dengan mata pelajaran program keahlian administrasi perkantoran, seperti kearsipan, korespondensi dan typing tutor sehingga prestasi 
belajar yang dicapai seharusnya lebih tinggi dibanding lulusan SMU. Kemampuan dan keterampilan yang dimiliki alumni SMK seyogyanya dikembangkan dan dapat dijadikan sebagai bekal dasar dalam proses perkuliahan (Suranto, 2015).

Berdasarkan hasil penelitian pendahuluan diperoleh informasi bahwa sebahagian besar mahasiswa lulusan SMK mendapat Indeks Prestasi Kumulatif (IPK) rata-rata $\geq 3,53$ yang sama dengan perolehan mahasiswa lulusan SMU bahkan lebih rendah dari mahasiwa lulusan SMU. Masih adanya gap tersebut, maka peneliti bermaksud mengkaji lebih mendalam perbandingan prestasi belajar mahasiswa lulusan SMU dan SMK dengan tujuan agar diperoleh temuan secara empiris dan dapat menemukan faktor-faktor yang mendukung dan menghabat prestasi belajar.

\section{METODE}

Penelitian ini dilakukan dengan menggunakan pendekatan kuantitatif, jenis ex post facto. Penelitian ini dilaksanakan pada program sudi Pendidikan Administrasi Perkantoran Fakultas Ilmu Sosial Universitas Negeri Makassar. Subjek penelitian mahasiswa angkatan 2016, 2017, 2018 dan 2019 lulusan SMU dan SMK. Populasi pada penelitian ini sebanyak 335 mahasiswa. Sampel penelitian sebanyak 167 mahasiswa yang diambil dengan metode probability sampling teknik proporsional random sampling.

Data dikumpulkan dengan teknik observasi, dokumentasi, wawancara. Data sekunder diperoleh melalui dokumentasi yang ada pada Sistem Informasi Akademik (SIA) untuk mengetahui jumlah mahasiswa aktif kuliah, latar belakang pendidikan mahasiswa, serta IPK mahasiswa. Teknik wawancara digunakan untuk mengetahui faktor yang mempengaruhi prestasi belajar mahasiswa. Untuk menganalisis deskriptif digunakan analisis rata-rata dan persentase dan pengujian hipotesis digunakan uji $\mathrm{F}$, anova, dan t-Test.

\section{HASIL DAN PEMBAHASAN}

\section{Hasil Penelitian}

Untuk mengetahui prestasi belajar mahasiswa lulusan SMU dan SMK, data yang diolah dan disajikan merupakan data yang diperoleh melalui teknik dokumentasi dimana instrumen penelitiannya dibuat sendiri oleh peneliti berupa lembar atau daftar isian Indeks Prestasi Kumulatif (IPK) dan latar belakang pendidikan mahasiswa. Selanjutnya, dilakukan uji kuantitaif dengan rumus statistik dengan bantuan software dengan program SPSS 21. 
Edisi Februari 2021, Volume 18, Nomor 1, ISSN 1412-1131, e-ISSN 2528-5750, Halaman 29-44

\section{Prestasi Belajar Mahasiswa Lulusan SMU dan SMK}

Dalam perkuliahan, setiap mahasiswa dituntut berkompetisi agar dapat memperoleh prestasi akademik yang diharapkan dalam hal ini IPK. Semakin baik penguasaan akademik pada proses pembelajaran, maka prestasi akademik yang dicapai semakin baik. Hasil analisis mengenai gambaran prestasi yang diperoleh mahasiswa yang berlatar belakang SMU dan SMK disajikan pada Tabel 1 berikut.

Tabel 1. Prestasi Mahasiswa Lulusan SMU dan SMK Semester Genap Tahun 2019

\begin{tabular}{ccccccc}
\hline & $\mathrm{N}$ & Min. & Max. & Sum & Mean & Std. Deviation \\
\hline SMU & 123 & 2.50 & 4.00 & 457.52 & 3.7197 & .22066 \\
SMK & 44 & 3.40 & 4.00 & 165.73 & 3.7666 & .17130 \\
\hline
\end{tabular}

Tabel 1 memberian gambaran bahwa prestasi belajar atau IPK mahasiswa lulusan SMK rata-rata sebesar 3,77, dan mahasiswa lulusan SMU yaitu sebesar 3,72. Adapun kategori prestasi belajar mahasiswa predikat lulusan dirinci pada Gambar 1 dan 2.

Apabila pengkategorian prestasi belajar mahasiswa dianalisis secara sendiri-sendiri seperti pada gambar 1 dan 2, dan disesuaikan dengan penentuan predikat kelulusan mahasiswa sesuai dengan standar Indeks Prestasi Kumulatif (IPK), maka diketahui bahwa prestasi belajar dari 123 mahasiswa lulusan SMU yang dijadikan sampel penelitian yaitu sebanyak $0,8 \%$ atau 1 orang berkategori memuaskan, 10,57\% atau 13 orang berkategori sangat memuaskan dan $88,62 \%$ atau 109 orang berkategori pujian atau cumlaude dan dari 44 mahasiswa yang dijadikan sampel penelitian pada kelompok mahasiswa lulusan SMK, tidak ada yang memperoleh kategori memuaskan. Kategori sangat memuaskan sebesar $6,82 \%$ atau 3 orang dan 93,18\% atau 41 orang memperoleh prestasi belajar atau Indeks Prestasi Kumulatif (IPK) berkategori pujian atau cumlaude. Dengan demikian terlihat bahwa prestasi mahasiswa lulusan SMU dan SMK sama-sama berada pada kategori pujian/ cumlaude.

\section{Kategori IPK Mahasiswa LulusanSMU}

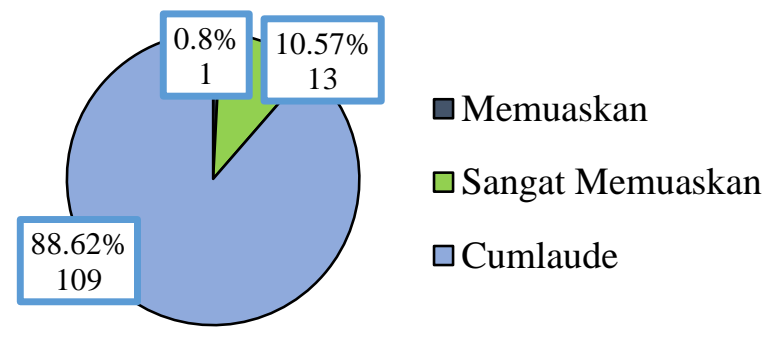

Gambar 1. Persentase Kategori Prestasi Belajar Mahasiswa Lulusan SMU 


\section{Kategori IPK Mahasiswa LulusanSMK}

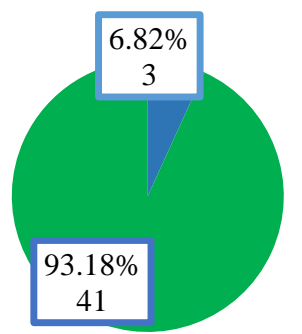

- Sangat Memuaskan

- Cumlaude

Gambar 2. Persentase Kategori Prestasi Belajar Mahasiswa Lulusan SMK

\section{Perbedaan Prestasi Belajar Mahasiswa Lulusan SMU dan SMK}

Hasil analisis data dengan menggunakan rumuas anava dan uji-t dapat dilihat pada Tabel 2 dan Tabel 3. Berdasarkan hasil pengujian hipotesis dengan menggunakan anava diperoleh $\mathrm{F}$ hitung $1,634<$ dari $\mathrm{F}$ tabel dk pembilang $1 \mathrm{dan} \mathrm{dk}$ penyebut 165 pada taraf signifikansi 5\% sebesar 3,90 dan hasil Anava 0,203 > 0,05, maka kedua kriteria pengujian hipotesis tersebut membuktikan $\mathrm{H}_{0}$ diterima dan $\mathrm{H}_{\mathrm{a}}$ ditolak. Selanjutnya, berdasarkan hasil uji t-test antara kelompok sampel lulusan SMU dan SMK didapat t hitung 1,278 dengan nilai signifikansi t hitung $0,203 \mathrm{dk}=\mathrm{N}_{1}+\mathrm{N}_{2}-2=123+44-2=165$ pada taraf signifikansi $5 \%$, maka nilai t tabel 1,97445. Dari hasil t-test kelompok sampel SMU dan SMK, diketahui nilai $\mathbf{t}$ hitung $<\mathbf{t}$ tabel $(0,203>0,05)$, maka $\mathrm{H}_{0}$ diterima dan $\mathrm{H}_{\mathrm{a}}$ ditolak sehingga dapat disimpulkan bahwa tidak terdapat perbedaan yang signifikan antara prestasi belajar mahasiswa lulusan SMU dan lulusan SMK.

Tabel 2. Hasil Uji Hipotesis (Uji Anava)

\begin{tabular}{cccccc}
\hline & Sum of Squares & df & Mean Square & F & Sig. \\
\hline Between Groups & .071 & 1 & .071 & 1.634 & .203 \\
Within Groups & 7.202 & 165 & .044 & & \\
\hline Total & 7.274 & 166 & & \\
\hline
\end{tabular}

Tabel 3. Hasil Uji T-Test Kelompok SMU dan SMK

\begin{tabular}{|c|c|c|c|c|c|c|c|c|c|c|}
\hline & & \multicolumn{3}{|c|}{$\begin{array}{c}\text { Levene's Test } \\
\text { for Equality of } \\
\text { Variances } \\
\end{array}$} & \multicolumn{6}{|c|}{ t-test for Equality of Means } \\
\hline & & \multirow[t]{2}{*}{$\mathrm{F}$} & \multirow[t]{2}{*}{ Sig. } & \multirow[t]{2}{*}{$\mathrm{T}$} & \multirow[t]{2}{*}{ df } & \multirow[t]{2}{*}{$\begin{array}{l}\text { Sig. } \\
(2- \\
\text { tailed })\end{array}$} & \multirow[t]{2}{*}{$\begin{array}{c}\text { Mean } \\
\text { Difference }\end{array}$} & \multirow[t]{2}{*}{$\begin{array}{l}\text { Std. Error } \\
\text { Difference }\end{array}$} & \multicolumn{2}{|c|}{$\begin{array}{l}95 \% \text { Confidence } \\
\text { Interval of the } \\
\text { Difference }\end{array}$} \\
\hline & & & & & & & & & Lower & Upper \\
\hline \multirow[b]{2}{*}{ IPK } & $\begin{array}{c}\text { Equal } \\
\text { variances } \\
\text { assumed }\end{array}$ & .493 & .483 & $1 . \overline{-}^{-}$ & 165 & .203 & -.04692 & 0.3670 & $\begin{array}{c}- \\
.11938\end{array}$ & .02555 \\
\hline & $\begin{array}{c}\text { Equal } \\
\text { variances } \\
\text { not } \\
\text { assumed }\end{array}$ & & & 1.439 & 97.136 & .153 & -.04692 & .03260 & $\begin{array}{c}- \\
.11162\end{array}$ & .01779 \\
\hline
\end{tabular}




\section{Faktor Pendukung dan Penghambat Prestasi Belajar Mahasiswa Lulusan SMU dan SMK}

Hasil wawancara menunjukkan bahwa faktor pedukung dan penghambat prestasi belajar mahasiswa, antara lain:

1. Faktor yang berpengaruh dalam upaya meningkatkan prestasi belajar, yaitu:

a. Adanya motivasi dari dalam dan faktor pendukung prestasi belajar untuk memperoleh IPK yang tinggi adalah dengan rajin kuliah dan rajin mengerjakan tugas.

b. Kemampuan individu memahami materi yang diberikan. Wawasan yang luas atau inteligensi yang dimiliki setiap mahasiswa akan mendukung mahasiswa mendapat hasil belajar yang tinggi.

c. Posisi tempat duduk, apabila duduk di belakang sulit untuk bisa fokus.

d. Memiliki orientasi kedepan atau tujuan dengan memandang kedepan pasti akan sukses dalam belajar, yang akan mendukung dia bisa mendapat prestasi yang bagus.

e. Aktif dalam aktifitas perkuliahan, menjawab pertanyaan dari dosen dan aktif dalam diskusi maupun proses pembelajaran lainnya.

f. Manajemen waktu yang baik merupakan faktor pendukung prestasi belajar. Mahasiswa harus pintar membagi waktu, antara waktu mengerjakan tuas rumah, tugas kuliah dan organisasi.

g. Suasana belajar. Mahasiswa selalu suka suasana belajar yang tenang, misalnya belajar diwaktu malam hari itu bisa membuat lebih fokus belajar.

h. Cara mengajar dosen. Dosen yang menarik, bisa berbaur dengan mahasiswa mengakibatkan mahasiswa dapat dengan mudah menerima materi pembelajaran.

2. Faktor penghambat prestasi belajar mahasiswa, yaitu:

a. Sifat malas dari diri mahasiswa itu sendiri.

b. Kurang motivasi mengikuti perkulihan

c. Tempat tinggal yang jauh dari kampus;

d. Jadwal kuliah sore. Fokus dan konsentrasi dalam kelas terganggu, karena semakin siang atau sore jadwal kuliah konsentrasi kami buyar yang menyebabkan kami tidak semangat lagi dalam menerima materi perkuliahan.

e. Cara mengajar dosen yang cenderung monoton (seperti menggunakan metode ceramah) membuat mahasiswa mengantuk dan jenuh untuk memperhatikan materi perkuliahan.

f. Lingkungan belajar tidak kondusif juga mempengaruhi mahasiswa dalam belajar. 
g. Kegiatan ekstra kampus seperti Lembaga Kemahasiswaan yang diikuti mahasiswa bersamaan dengan kegiatan kuliah.

Dari beberapa pendapat tersebut dapat dipahami bahwa beberapa faktor yang menjadi penghambat prestasi belajar mahasiswa antara lain: malas, tidak adanya dorongan (motivasi), jarak tempat tinggal yang jauh dari kampus, persepsi mahasiswa "salah jurusan" jadwal kuliah sore, metode pembelajaran yang monoton, dan lingkungan belajar yang tidak kondusif.

\section{Pembahasan Hasil Penelitian}

\section{Prestasi Belajar Mahasiswa Lulusan SMU dan SMK}

Prestasi merupakan hasil dari pengukuran, evaluasi, dan penilaian yang dilakukan oleh pendidik. Hasil belajar selanjutnya diinterprestasikan dalam bentuk nilai. Hasil belajar tersebut merupakan tingkat kemampuan mahasiswa dalam jangka waktu tertentu setelah mengikuti proses pembelajaran/perkuliahan yang disusun dan direncanakan sedemikian rupa oleh dosen. Beberapa fungsi prestasi belajar yang dijadikan tolok ukur bagi pendidik dalam mentukan hasil dari proses pembelajaran, antara lain:

1. Indikator keberhasilan dari aspek kogninif, afktif, dan psikomotorik mahasiswa setelah mengikuti pembelajaran.

2. Sebagai symbol dalam penguasaan materi pembelajaran dan hasrat ingin tahu peserta didik;

3. Sebagai data dan informasi bagi lembaga pendidikan dalam rangka melakukan inovasi pendidikan dan pembelajaran;

4. Sebagai indikator keberhasilan atau kegagalan institusi pendidikan;

5. Indikator untuk mengetahui daya serap peserta didik dalam mengikuti pembelajaran;

6. Sebagai bahan evalusi bagi pendidik (dosen) terhadap pembejaran yang telah dilakukan, dan

7. Sebagai acuan dalam melaksanakan pembelajaran remedial dan tindak lanjut dari kegiatan pembelajaran.

Pengukuran dan penilaian prestasi belajar mahasiswa dengan skala 0,0 - 4,0 atau skala huruf A sampai E digunakan sebagai indikator keberhasilan belajar mahasiswa setelah proses pembelajaran dilakukan. Acuan tersebut merupakan dasar bagi dosen untuk menentukan prestasi belajar mahasiswa dan merupakan patokan umum yang telah ditetapkan dalam peraturan akademik. 
Berdasarkan hasil analisis data diketahui bahwa IPK mahasiswa lulusan SMK sebesar 3,77, lebih tinggi dibandingkan dengan IPK mahasiswa lulusan SMU yaitu sebesar 3,72. Prestasi belajar atau Indeks Prestasi Kumulatif (IPK) dari 123 mahasiswa lulusan SMU yang dijadikan sampel penelitian $0,8 \%$ atau 1 orang berkategori memuaskan, 10,57\% atau 13 orang berkategori sangat memuaskan dan 88,62\% atau 109 orang berkategori pujian atau cumlaude. 44 mahasiswa yang dijadikan sampel penelitian pada kelompok mahasiswa lulusan SMK, tidak ada yang memperoleh kategori memuaskan. Kategori sangat memuaskan sebesar $6,82 \%$ atau 3 orang dan kategori pujian atau cumlaude sebesar 93,18\% atau 41 orang.

Penelitian yang dilakukan oleh Lesmana Hendy, dkk disebutkan bahwa indeks prestasi mahasiswa latar belakang SMK lebih tinggi dibandingkan dengan rata-rata indeks prestasi mahasiswa latar belakang SMA (Lesmana, 2016). Hal tersebut dapat disebabkan oleh mahasiswa lulusan SMK telah memiliki pengalaman tentang program keahlian perkantoran sehingga dalam proses perkuliahan/pembelajaran tidak mengalami hambatan dan dapat lebih mudah mengikuti proses perkuliahan. Selain itu, mahasiswa lulusan SMK mempunyai kemampuan beradaptasi yang baik pada struktur perkuliahan di Program Studi Pendidikan Administrasi Perkantoran yang lebih mengedepankan Skill dibandingkan dengan knowledge.

SMU merupakan jenis pendidikan umum yang aktivitas pembelajarannya lebih menitikberatkan pada pengetahuan yang bersifat teoritis. Jenis pendidikan SMU bertujuan mengembangkan aspek kognitif/pengetahuan yang dibutuhkan oleh siswa untuk melanjutkan ke jenjang Pendidikan tinggi. SMU terdiri atas beberapa lembaga pendidikan yaitu SMA dan MA. Pada jenis pendidikan SMU dan SMK aspek psikomotorik dilatih melalui kegiatan praktik keterampilan, aspek kognitif difokuskan melalui pengajaran yang bersifat teoritik serta terdapat pembinaan aspek sikap. Muatan aspek kognitif dan praktek jelas berbeda, karena berdasarkan pada kurikulum yang berbeda. Pendidikan kejuruan merupakan lembaga yang mempersiapkan siswa siap kerja dalam bidang tertentu. Tidak terbatas akan hal itu, siswa lulusan SMKdapat pula melanjutkan Pendidikan ke perguruan tinggi yang diinginkan. Adapun kompetensi keahlian yang dipelajari akan lebih diperdalam di tingkat perguruan tinggi. Muatan aspek kognitif dan praktek jelas berbeda pada jenis pendidikan SMU dan SMK, karena kurikulum yang digunakan pada satuan pendidikan tersebut juga yang berbeda. Selain kurikulum, metode belajar juga berbeda. Siswa SMK lebih banyak dilatih untuk mengembangkan keahlian melalui praktek belajar. 


\section{Perbedaan Prestasi Belajar Mahasiswa Lulusan SMU dan SMK}

Prestasi belajar yang diidentikkan dengan Indeks Prestasi Kumulatif (IPK) mahasiswa lulusan SMK lebih tinggi dibandingkan dengan IPK yang mahasiswa lulusan SMU. Berdasarkan hasil uji analisis varian (anava) dan uji t diketahui bahwa tidak ada prestasi belajar mahasiswa lulusan SMU dan SMK. Hasil tersebut tidak sesuai hasil penelitian yang menyatakan bahwa prestasi belajar dipengaruhi oleh kualitas belajar, pengalaman belajar (latar belakang pendidikan), kurikulum, cara menerima pelajaran, hubungan dengan pendidik, stres, dan keterampilan sosial (Dewi, 2015). Berdasar pada pendapat tersebut, kualitas belajar dan pengalaman belajar tidak berpengaruh terhadap prestasi yang diperoleh mahasiswa. Hal ini dimungkinkan karena pola kegiatan pembelajaran seperti penerapan metode diskusi yang dijadikan tolak ukur untuk mendapatkan nilai tinggi adalah mahasiswa yang aktif memberikan tanggapan maupun sanggahan dalam diskusi. (Muslihudin \& Arumita, 2016). Hal tersebut juga terjadi saat menggunakan metode penugasan, tugas-tugas yang diberikan memiliki tingkat kesulitan rendah, tidak memerlukan analisis yang mendalam sehingga mahasiswa lulusan SMU dan SMK dengan mudah mengerjakannya dan mendapat nilai yang sama. Hal ini dimungkinkan karena faktor internal dari dalam diri mahasiswa, seperti, intelegensia, kurangnya motivasi belajar, tidak serius dalam mencari referensi (Sayidani et al., 2016).

Pendidikan di SMU dititikberatkan pada pembelajaran yang bersifat teoritis dan di SMK dititik beratkan pada praktek keterampilan. Hal ini berarti mahasiswa yang berlatar belakang SMU dilatarbelakangi oleh pengajaran yang mengutamakan ilmu yang berisfat teoritis dan yang berlatar belakang SMK dilatarbelakangi oleh pendidikan yang bersifat praktek keterampilan keahlian, maka seyogianya mereka yang berlatar belakang SMK dijadikan sebagai input (mahasiswa baru) pada Program Studi Pendidikan Administrasi Perkantoran sehingga output yang dihasilkan lebih berkualitas. Prestasi akademik terutama aspek pengetahuan penting bagi mahasiswa. Namun demikian, prestasi nonakademik pun dibutuhkan karena sifatnya tidak dapat diukur seperti emosi, kreatifitas, imajinasi. Apabila mahasiswa memiliki prestasi akademik tetapi tidak memiliki prestasi non-akademik seperti prestasi dalam bidang kegiatan ektrakurikuler (olahraga, seni, dan kegiatan pengembangan bakat lainnya) akan kesulitan dalam kehidupannya kelak. Prestasi non akademik memberikan pengalaman dalam melaksanakan kegiatan terutama yang membutuhkan kemampuan motorik, sehingga diharapkan mahasiswa memiliki leadership skill yang dibawa sejak mengikuti kegiatan non-akademik. 
Edisi Februari 2021, Volume 18, Nomor 1, ISSN 1412-1131, e-ISSN 2528-5750, Halaman 29-44

\section{Faktor yang Mendukung dan Menghambat Pencapaian Prestasi Belajar Mahasiswa Lulusan SMU dan SMK}

Hasil peneltian menunjukkan bahwa prestasi belajar dipengaruhi oleh faktor internal maupun faktor eksternal. Faktor internal merupakan keadaan yang berhubungan dengan kondisi peserta didik (siswa/mahasiswa), baik jasmani maupun rohani (psikologis). Prestasi belajar siswa/mahasiswa yang dipengaruhi oleh faktor jasmani yaitu dapat berupa kondisi kesehatan, cacat tubuh yang dideritanya, maupun tingkat kelelahan mengikuti pembelajaran. Faktor psikologis yang dapat berpengaruh terhadap hasil belajar dapat berupa perhatian, minat, tingkat intelegensi, bakat, dan motivasi. Selain itu faktor keluarga khususnya orangtua juga memegang peranan penting dalam menentukan hasil belajar sehingga diharapkan agar orang tua berperan aktif mengontrol anaknya (siswa/mahasiswa) dalam belajar terutama di rumah. (Alfiyah \& Hisyam, 2015).

Secara empiris, hasil penelitian memberikan gambaran bahwa ada beberapa faktor pendukung prestasi belajar, mahasiswa antara lain: motivasi belajar, inteligensi, konsentrasi, ada tujuan yang ingin dicapai, rajin kuliah dan mengerjakan tugas, keaktifan dalam proses perkuliahan, manajemen waktu yang baik, suasana belajar yang kondusif, dan hubungan mahasiswa dengan dosen. Faktor penghambat prestasi belajar mahasiswa antara lain: malas; tidak ada motivasi; jarak tempat tinggal yang jauh dari kampus; persepsi mahasiswa "salah jurusan"; jadwal kuliah sore; metode pembelajaran yang monoton; dan lingkungan belajar yang tidak kondusif.

Beberapa faktor pendukung sehingga prestasi belajar mahasiswa yang berasal dari SMU dapat bersaing dengan alumni SMK, antara lain:

1. Keaktifan dalam proses perkuliahan seperti aktif dalam menjawab pertanyaan dari dosen dan aktif dalam diskusi maupun proses pembelajaran lainnya.

2. Manajemen waktu yang baik antara waktu mengerjakan tugas rumah, tugas kuliah dan organisasi.

3. Suasana belajar yang kondusif. Mahasiswa biasanya suka suasana belajar yang tenang, misalnya belajar diwaktu malam hari itu bisa membuat lebih fokus belajar. Mahasiswa lebih banyak belajar dan mengerjakan tugas di rumah dari pada di kampus atau di perpustakaan karena di rumah suasana lebih kondusif.

4. Hubungan mahasiswa dengan dosen. Hubungan baik antara mahasiswa dengan dosen dapat mendukung prestasi belajar. 
Faktor penghambat prestasi belajar mahasiswa antara lain: malas mengerjakan tugas kuliah yang diberikan oleh dosen, kurangnya dorongan (motivasi), jarak tempat tinggal yang jauh dari kampus, masih adanya persepsi mahasiswa yang menganggap dirinya salah jurusan, jadwal kuliah sore yang menyebabkan mahasiswa malas kuliah, metode pembelajaran yang digunakan dosen monoton, dan lingkungan belajar yang kurang kondusif. Hasil didukung oleh hasil penelitian yang dilakukan (Dewi, 2015) menyatakan bahwa prestasi belajar dapat dipengaruhi oleh pilihan jurusan, tempat tinggal, jalur masuk, metode dan motivasi belajar, serta dukungan orang tua (Niswaty \& Arhas, 2019); (Choe, 2020).

Hasil penelitian yang diperoleh mengindikasikan bahwa prestasi belajar mahasiswa bukan hanya ditentukan oleh jenjang dan jenis pendidikan sebelumnya, akan tetapi juga lebih banyak dipengaruhi oleh faktor internal seperti: konsep diri dari seorang peserta didik akan menentukan prestasi yang dimilikinya. minat, motivasi, dan kemandirian mahasiswa itu sendiri serta faktor ekternal seperti lingkungan tempat tinggal, metode belajar, cara mengajar dosen, dan dukungan keluarga. Walaupun faktor internal dan ekternal mempengaruhi prestasi belajar mahasiswa, namun demikian perlu bagi pimpinan program studi untuk tetap memperhatikan dan meningkatkan kualitas proses pembelajaran/perkuliahan mahasiswa karena hal tersebut menunjang prestasi belajar mahasiswa.

\section{KESIMPULAN}

Prestasi belajar mahasiswa lulusan Sekolah Menengah Umum berdasarkan rata-rata IPK sebesar 3,72, dengan rincian: $0,8 \%$ atau 1 orang berkategori memuaskan, 10,57\% atau 13 orang berkategori sangat memuaskan dan $88,62 \%$ atau 109 orang berkategori pujian atau cumlaude. 44 mahasiswa yang dijadikan sampel penelitian pada kelompok mahasiswa lulusan SMK, tidak ada yang memperoleh kategori memuaskan, memperoleh kategori sangat memuaskan yaitu sebesar $6,82 \%$ atau 3 orang dan $93,18 \%$ atau 41 orang memperoleh prestasi belajar atau Indeks Prestasi Kumulatif (IPK) berkategori pujian atau cumlaude. Hasil uji hipotesis ditemukan bahwa tidak terdapat perbedaan antara prestasi belajar mahasiswa lulusan Sekolah Menengah Umum dan Sekolah Menengah Kejuruan

Faktor pendukung prestasi belajar, antara lain: motivasi, inteligensi, konsentrasi, ada tujuan yang ingin dicapai, rajin kuliah dan mengerjakan tugas, keaktifan dalam proses perkuliahan, manajemen waktu yang baik, suasana belajar yang kondusif, dan hubungan mahasiswa dengan dosen. Faktor penghambat antara lain: malas, tidak ada motivasi, jarak 
tempat tinggal yang jauh dari kampus, persepsi mahasiswa salah jurusan, jadwal kuliah sore, metode pembelajaran yang monoton, dan lingkungan belajar yang tidak kondusif. Hasil penelitian ini, dapat menjadi acuan untuk melihat kembali kebijakan akademik yang diterapkan khususnya dalam proses pembelajaran untuk selanjutnya melakukan perbaikan demi kemajuan program studi kedepan. Dengan demikian prestasi belajar mahasiswa dapat lebih meningkat sesuai yang diharapkan.

Penelitian ini menggunakan pengukuran self-report yang dapat memunculkan common method bias terjadi karena keterbatasan peneliti dalam mengontrol jawaban responden sehingga tidak menggambarkan kondisi sebenarnya. Jumlah sampel pada penelitian ini terbatas, sehingga hasil penelitian yang diperoleh belum merepresentasikan populasi secara keseluruhan sehingga generalisasi hasil penelitian perlu dilakukan dengan sangat hati-hati.

Kebijakan pemberian nilai kepada mahasiswa dengan mengedepankan aspek kognitif menyebabkan tidak adanya perbedaaan prestasi belajar mahasiswa lulusan SMU dan SMK memberikan indikasi bahwa proses pembelajaran di Program Studi Pendidikan Administrasi Perkantoran perlu ditinjau kembali. Seyogyanya mahasiswa lulusan SMK khususnya dari rumpun Administrasi Perkantoran memiliki prestasi belajar yang lebih tinggi dibandingkan lulusan SMU. Oleh karena itu, tenaga pendidik (dosen) perlu memperhatikan semua aspek penilaian, baik aspek kognitif, afektif, lebih khusus pada aspek psikomotorik. Mahasiswa perlu dibekali keterampilan khususnya pada mata kuliah produktif agar mampu bersaing di dunia kerja kelak. Bagi peneliti berikutnya disarankan untuk lebih fokus untuk menganalisis proses penialaian dosen dan dapat menambah variabel yang penting agar penelitian ini dapat lebih maksimal.

\section{DAFTAR PUSTAKA}

Akçay, C., \& Akyol, B. (2014). Self-Actualization Levels of Participants in Lifelong Education Centers. Procedia-Social and Behavioral Sciences, 116, 1577-1580. https://doi.org/https://doi.org/10.1016/j.sbspro.2014.01.437.

Alfiyah, N., \& Hisyam, D. (2015). Hubungan antara Kemandirian Belajar dan Lingkungan Belajar dengan Prestasi Belajar Mahasiswa Prodi Pendidikan Administrasi Perkantoran Angkatan 2010 FIS-UNY. Efisiensi : Kajian Ilmu Administrasi. https://doi.org/10.21831/efisiensi.v12i1.3866.

Arhas, S. H. (2018). Metode Pembelajaran Black Knight. Apa? Mengapa? dan Bagaimana? Jurnal Ad'ministrare, 5(2), 165-172.

Choe, D. (2020). Parents' and adolescents' perceptions of parental support as predictors of 
adolescents' academic achievement and self-regulated learning. Children and Youth Services Review. https://doi.org/10.1016/j.childyouth.2020.105172.

Darwis, M., Amelia, D., \& Arhas, S. (2019). The Influence of Teaching Variations on Student Learning Motivation at State Vocational High School 4 Makassar. International Conference on Social Science 2019 (ICSS 2019).

Darwis, M., Batari, U. D., Salam, R., Kasmita, M., \& Baharuddin, A. (2019). Pengaruh Kompetensi Profesional Guru Terhadap Kualitas Proses Pembelajaran Pada Paket Keahlian Administrasi Perkantoran Di SMK Negeri 1 Gowa. Jurnal Ad'ministrare, 5(2), 105-112.

Dewi, A. P. (2015). Hubungan antara kualitas tidur dan kuantitas tidur dengan prestasi belajar mahasiswa. 2 No.2.

Hamdu, G., \& Agustina, L. (2011). Pengaruh motivasi belajar siswa terhadap prestasi belajar IPA di sekolah dasar. Jurnal Penelitian Pendidikan, 12(1), 90-96.

Hikmawati, F. (2018). Metodologi penelitian (1st ed.). PT. Raja Grafindo Persada.

Hosnan. (2014). Pendekatan Saintifik dan Kontekstual Dalam Pembelajaran Abad 21 (R. Sikumbang (ed.); 1st ed.). Ghalia Indonesia.

Ikhsan, M. I., Niswaty, R., Saleh, S., \& Arhas, S. H. (2019). The Effectiveness of Using the Lecture Method at SMK Negeri 1 Parepare. PINISI Discretion Review, 3(2), 151-156.

Jansen, R. S., van Leeuwen, A., Janssen, J., Jak, S., \& Kester, L. (2019). Self-regulated learning partially mediates the effect of self-regulated learning interventions on achievement in higher education: A meta-analysis. Educational Research Review, 28, 100292. https://doi.org/https://doi.org/10.1016/j.edurev.2019.100292.

Lesmana, H. (2016). Analisis Komparatif Hasil Studi Mahasiswa Latar Belakang SMK dan SMA di Fakultas Ilmu KesehatanUniversitas Borneo Tarakan. Jurnal Ilmiah IlmuIlmu Kesehatan, 14(1), 18-31. https://doi.org/10.1017/CBO9781107415324.004.

Liu, H., Yao, M., \& Li, J. (2020). Chinese adolescents' achievement goal profiles and their relation to academic burnout, learning engagement, and test anxiety. Learning and Individual Differences, 101945. https://doi.org/https://doi.org/10.1016/j.lindif.2020.101945.

Mardiyah, S. U. K., Sutirman, S., \& Ramadhan, A. N. (2017). Penguasaan Keterampilan Mengajar Mahasiswa Prodi Pendidikan Administrasi Perkantoran Pada Mata Kuliah Pembelajaran Mikro Tahun 2015. Efisiensi - Kajian Ilmu Administrasi. https://doi.org/10.21831/ efisiensi.v13i2.11682.

Muslihudin, M., \& Arumita, A. W. (2016). PEMBUATAN Model Penilaian Proses Belajar Mengajar Perguruan Tinggi Menggunakan Fuzzy Simple Additive Weighting (Saw) (Sudi : Stmik Pringsewu). Seminar Nasional Teknologi Informasi Dan Multimedia.

Muslimin, M., Saleh, S., \& Darwis, M. (2019). Implementation of the Use of Lecture Method in Filing Subjects at the Department of Office Vocational School YPLP PGRI 1 Makassar. Jurnal Ad'ministrare, 6(2), 95-104. 
Nasrullah, M., Ilmawati, I., Saleh, S., Niswaty, R., \& Salam, R. (2018). Minat Menjadi Guru Pada Mahasiswa Program Studi Pendidikan Administrasi Perkantoran Fakultas Ilmu Sosial Universitas Negeri Makassar. Jurnal Ad'ministrare.

Nasrullah, N. (2017). Communication Strategies Employed by the Fourth Semester Students of English Department of State University of Makassar. Jurnal Ad'ministrare: Jurnal Pemikiran Ilmiah Dan Pendidikan Administrasi Perkantoran, 4(2), 83-96.

Niswaty, R., \& Arhas, S. H. (2019). The Effect of Learning Media on Progress Quality in Office Administration Program in Vocational School Negeri 1 Watampone Bone Regency. Journal of Physics: Conference Series, 1387. https://doi.org/10.1088/17426596/1387/1/012042.

Pope, N. G. (2019). The effect of teacher ratings on teacher performance. Journal of Public Economics, 172 ,

84-110. https://doi.org/https://doi.org/10.1016/j.jpubeco.2019.01.001.

Sayidani, A., Irianto, W. S. G., \& Fuady, M. J. (2016). Perbandingan Prestasi Belajar Mahasiswa Lulusan Sma Dan Smk Pada Prodi S1 Pendidikan Teknik Informatika Universitas Negeri Malang. Teknologi Dan Kejuruan, 39(2), 157.

Schrader, C., \& Grassinger, R. (2021). Tell me that I can do it better. The effect of attributional feedback from a learning technology on achievement emotions and performance and the moderating role of individual adaptive reactions to errors. $\begin{array}{llll}\text { Computers \& Education, } & 104028 .\end{array}$ https://doi.org/https://doi.org/10.1016/j.compedu.2020.104028.

Sung, E. (2017). The influence of visualization tendency on problem-solving ability and learning achievement of primary school students in South Korea. Thinking Skills and Creativity, 26, 168-175. https://doi.org/https://doi.org/10.1016/j.tsc.2017.10.007.

Suprianto, S., Arhas, S. H., \& Salam, R. (2018). Pengaruh Media Pembelajaran dan Pengelolaan Kelas terhadap Prestasi Belajar Siswa di SMK Negeri Kecamatan Tanete Riattang, Kabupaten Bone. Jurnal Ad'ministrare, 5(2), 137-146.

Suranto. (2015). Peningkatan Mutu Pendidikan Kejuruan Berorientasi Pasar Kerja Melalui Uji Kompetensi Keahlian. Efisiensi : Kajian Ilmu Administrasi. https://doi.org/10.21831/efisiensi.v12i1.3862.

Widowati, S. (2017). Hubungan tingkat kecemasan dengan prestasi belajar pada mahasiswa program d3 keperawatan. Research Report.

Yusman, I. Y., Ismiyati, I., \& Mar'atus Sholikah, M. (2019). Pengaruh OJT, Prestasi Belajar, Informasi Kerja, dan Motivasi Kerja Terhadap Kesiapan Kerja Siswa SMK. Efisiensi : Kajian Ilmu AdministrasI. https://doi.org/10.21831/efisiensi.v16i1.24476.

\section{UCAPAN TERIMA KASIH}

Para dosen dan staf tenaga kependidikan Fakultas Ilmu Sosial Universita Negeri

Makassar. Para dosen dan pimpinan jurusan yang selalu memberikan dorongan kepada 
kami untuk meneliti di Prodi demi pengembangan program studi Pendidikan Administrasi Perkantoran khususnya Ketua Jurusan Ilmu Administrasi Bapak Prof. Dr. Haedar Akib, M.Si., dan Kaprodi Pendidikan Administrasi Perkantoran Bapak Muh. Darwis, S.Pd., M.Pd. Terima kasih pula kami sampaikan kepada Redaksi Efisiensi yang selalu memberikan saran agar artikel ini dapat diterbitkan.

\section{PROFIL PENULIS}

Dr. Sirajuddin Saleh, S.Pd., M.Pd., Dosen pada Program Studi Pendidikan Administrasi Perkantoran FIS Universitas Negeri Makassar. Menyelesaikan pendidikan Sarjana (S1) pada Jurusan Administrasi Pendidikan Fakultas Ilmu Pendidikan IKIP Ujung Pandang tahun 1996. Magister (S2) Administrasi Pendidikan pada PPS Universitas Negeri Makassar tahun 2011, Doktor (S3) bidang Ilmu Pendidikan pada PPs Universitas Negeri Makassar tahun 2020. Sinta ID: 6037633. Muh. Nasrullah, S.Pd., M.Pd. Dosen pada jurusa Ilmu Administrasi. Menyelesaikan Pendidikan sarjana pada Program Studi Pendidikan Administrasi Perkantoran FIS UNM tahun 2003. Magister (S2) Pendidikan Administrasi Umum pada PPS Universitas Negeri Makassar tahun 2015. Sinta ID: 6674433. Jufari, S.Pd. Alumni Program Studi Pendidikan Administrasi Perkantoran Fakultas Ilmu Sosial Universitas Negeri Makassar. 